\title{
THE ASSOCIATIONS OF INTERNAL FACTORS, SOURCES OF INFORMATION, AND FAMILY ROLE WITH PREMARITAL SEXUAL BEHAVIOR AMONG ADOLESCENTS IN KUPANG, EAST NUSA TENGGARA
}

\author{
Diyan M. Kristin'), Pius weraman²), Sabina Gero') \\ 1) School of Health Sciences, Ministry of Health, Kupang \\ ${ }^{2)}$ Graduate Program, Nusa Cendana University
}

\begin{abstract}
Background: Earlier studies reported that parents play a significant role in the sexual development and behaviors of their children. Parental monitoring and supervision are important paths for keeping adolescents from risky situations and activities while the teen develops responsible decision-making skills. A supportive relationship between the parent and adolescent is important for enhancing communication and supervision. Empirical studies into this issue, however, is scanty in East Nusa Tenggara. This study aimed to analyze the associations of parental role and source of information on reproductive health, with unhealthy premarital sex behavior among adolescents in Kupang, East Nusa Tenggara.

Subjects and Method: This was a cross sectional study conducted in Kupang, East Nusa Tenggara. A sample of 90 adolescents were selected for this study. The dependent variable was unhealthy sex behavior. The independent variables were role of parents and source of information on reproductive health. The data were collected by questionnaire and analyzed by a multiple logistic regression.

Results: The risk of unhealthy premarital sex behavior increased with weak role of parents $(\mathrm{OR}=2.74 ; \mathrm{p}=0.045)$ and negative source of information on reproductive health $(\mathrm{OR}=2.20 ; \mathrm{p}=0.033)$.

Conclusion: The risk of unhealthy premarital sex behavior increases with weak role of parents and negative source of information on reproductive health.
\end{abstract}

Keywords: premarital, sex behavior, unhealthy, role of parents, source of information, reproductive health

\section{Correspondence:}

Diyan M. Kristin. Midwifey Program, School of Health Polytechnics, Ministry Health, Kupang. E-mail: kristindiyan@yahoo.co.id. Mobile : +6281339728135. 